\title{
Aluminum Electrodeposition from Room Temperature Molten AICI3-BPC Salt Bath
}

\author{
C.C. Yang \\ National Yunlin Institute of Technology Touliu, Yunlin, Taiwan 640, R.O.C. \\ C.P. Chang \\ National Yunlin Institute of Technology Touliu, Yunlin, Taiwan 640, R.O.C.
}

Follow this and additional works at: https://jmstt.ntou.edu.tw/journal

Part of the Mechanical Engineering Commons

\section{Recommended Citation}

Yang, C.C. and Chang, C.P. (1993) "Aluminum Electrodeposition from Room Temperature Molten AICI3-BPC Salt Bath," Journal of Marine Science and Technology. Vol. 1: Iss. 1, Article 6.

DOI: $10.51400 / 2709-6998.2476$

Available at: https://jmstt.ntou.edu.tw/journal/vol1/iss1/6

This Research Article is brought to you for free and open access by Journal of Marine Science and Technology. It has been accepted for inclusion in Journal of Marine Science and Technology by an authorized editor of Journal of Marine Science and Technology. 


\title{
ALUMINUM ELECTRODEPOSITION FROM ROOM TEMPERATURE MOLTEN AICl${ }_{3}$-BPC SALT BATH
}

\author{
C.C. Yang and C.P. Chang \\ National Yunlin Institute of Technology \\ Touliu, Yunlin, Taiwan 640, R.O.C.
}

Key words: electrodeposited layer, morphology, electrochemical polarization curves.

\begin{abstract}
The characteristics of aluminum electrodeposited layer from an ambient temperature molten salt were discussed in this study.

The experimental results indicated that it is possible to carry out aluminum electrodeposition on the surface of brass and stainless steel when binary $\mathrm{AlCl}_{3}-\mathrm{BPC}$ molten electrolysis were used. The morphology of the components, characteristics and images can be detected by SEM, Auger Analysis, $X$-ray diffraction analysis and electrochemical polarization curves. The denser and more adhesive electrodeposited aluminum layer can be achieved by chosing proper electrolyte components ( $\mathrm{AlCl}_{3}: B P C$-acidic salt bath), current forms (D.C./pulse), current density, electrolytic time and other pretreatment. In addition, the current density will be rised while the smaller particle size and better adhesive of electrodeposited layer formation by pulse current instead of direct current.
\end{abstract}

\section{INTRODUCTION}

The mixtures of $\mathrm{AlCl}_{3}$ and n-butylpyridinium chloride at room temperature which are melts have been proposed for using as electrolyte in recent years. The major applications include aluminum electrodeposition [1-5], possible electrolytes for molten salt batteries [6-7] and photoelectrochemical cell investigations [8-12].

Aluminum is a very important metal in industry owing to its excellent properties. The electrodeposition of $A l$ is restricted to electrolysis of molten salts since $A l$ is a very active metal and can not be electrodeposited from aqueous solution or from any protic solvent.

The purpose of the present work is studying the behavior of electrodeposition of aluminum from the room temperature $\mathrm{AlCl}_{3}$-n-butylpyridinium chloride melt which has been investigated by changing the variables, such as surface treatment of the substrate, the composition of electrolyte, current density, duration of electrodeposition, and the current form for the optimum operation conditions for aluminum electrodeposition on brass and stainless steel electrodes respectively.

\section{EXPERIMENTAL}

Aluminum chloride prepared industrially from aluminiferrous ores contains $\mathrm{FeCl}_{3}, \mathrm{SiCl}_{4}$ and $\mathrm{TiCl}_{4}$, of which the last two contaminants are readily separable due to the boiling point [13]. Most of the processes dealing with the industrial purification of $\mathrm{AlCl}_{3}$ are directed at the removal of the $\mathrm{FeCl}_{3}$ contamination by reduction to metallic iron with aluminum metal, then subsequent volatilization of the $\mathrm{AlCl}_{3}$ [14-17]. For the laboratory techniques are separation of the iron by D.C. electrolysis [18], or the purification of $\mathrm{AlCl}_{3}$ by sublimation from an $\mathrm{NaAlCl}_{4}$ bath after introduction of $\mathrm{Al}$ or $\mathrm{Fe}$ metallic chips, or the passage of reducing gases [19-20].

The sublimation of $\mathrm{AlCl}_{3}$ glass tubes was carried out at $220^{\circ} \mathrm{C}$ in the sealed pyrex glasstubes, which is consists of a pyrex vessel fitted with a cooling tube. A 
mixture of commerical aluminum chloride (90-95 $\mathrm{wt} \%)$ and $\mathrm{NaCl}(10-\mathrm{Swt} \%)$ and a small quantity of $\mathrm{Al}$ metal was added to the contents of the pyrex tube. Slowly raised temperature and melted the mixtures $\left(190-210^{\circ} \mathrm{C}\right)$, the $\mathrm{AlCl}_{3}$ evaporated and deposited on the cooling tube. The sublimation was kept to continue until the $\mathrm{AlCl}_{3}$ layer had sublimed and then the cooling tube was transferred carefully to another pyrex vessel, then shook to remove the white $\mathrm{AlCl}_{3}$ crystals, collected and stored in a desiccator. The recrystallition is necessary if the $\mathrm{AlCl}_{3}$ crystals were yellow-brown color, in which may contain impurities or $\mathrm{NaAlCl}_{4}$ layer.

$\mathrm{AlCl}_{3} \cdot \mathrm{BPC}$ melts were prepared by addition of $\mathrm{AlCl}_{3}$ to $\mathrm{BPC}$ with desired molar ratio, during addition, the reaction is exothermic and care must be taken to ensure that the temperature does not exceed $100^{\circ} \mathrm{C}$, otherwise thermal decomposition may occur.

The experimental setup for the aluminum electrodeposited process was shown in Fig. 1. The anode and cathode were aluminum (99.7\%) and brass sheet with $0.5 \mathrm{~mm}$ thick, $50 \mathrm{~mm}$ in length, $10 \mathrm{~mm}$ in width, respectively. All the electrodes were mechanically polishing with a number of $\mathrm{SiC}$ paper (Grade 220, $400,600,800,1000,1200$ ). The polished surface was washed with distilled water then dried and cleaned with acetone, and the electrodes were connected with

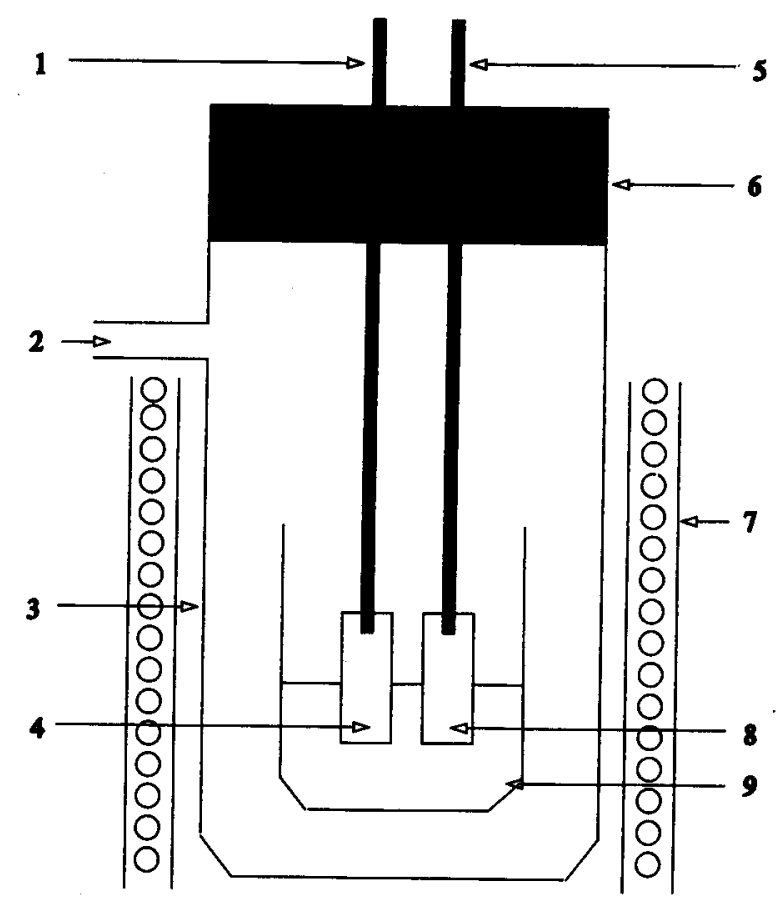

Fig. 1. The electrolysis cell for the aluminum electroplating:
1. Cathode
2. Gas Outlet
3. Pyrex Vessel
4. Substrate 5. Anode
6. Rubber Stopper
7. Heating Element
8. Pure Aluminum Plate

9. Molten Salt Electroyte. the Mo wire.

The purification of chemicals, preparation of the melts and electrodeposited process can be carried out under the protection of dehumidified and deoxygenated high purity $\mathrm{Ar}$ atmosphere by passing through concentrate $\mathrm{H}_{2} \mathrm{SO}_{4}$, annydrous $\mathrm{Mg}\left(\mathrm{ClO}_{4}\right)_{2}$ and hot activate copper heated with electrical furnace. For each electrodeposited process $A r$ was bubbled into the melt for about $10 \mathrm{~min}$. to stir the electrolytes.

The major operating conditions for the aluminum electrodeposited process in the present studies are the composition of electrolytes, current density, current forms (D.C. or pulse supply) and electrodeposition time.

After the electrodeposited process, the specimen was washed with distilled water, dried and stored in a desiccator for further analysis. The morphology and thickness of the electrodeposited layer was observed with SEM, EDS and Auger Depth profile to analysis the composition of the deposited layer, the $X$-ray diffraction meter was ultilized to investigated the structure and composition of film. D.C. polarization method was used to measured the corrosion resistance of the aluminum electrodeposited layer.

\section{RESULTS AND DISCUSSION}

The proper range of the $\mathrm{AlCl}_{3}$ to BPC for the $\mathrm{Al}$ electrodeposited process is about the molar ratio of $\mathrm{AlCl}_{3}$ : BPC from 1:1 to 1.86:1. Accordingly, a variety of composition have been used to performed the electrodeposited process in the present study.

From the experimental results, it is observed that a poor compact $\mathrm{Al}$ - electrodeposited layer occurs in the basic or neutral melts, accordingly, with increases the concentration of $\mathrm{AlCl}_{3}$, the dense and adhesive $\mathrm{Al}$ electrodeposited layer can be obtained. In the basic or neutral melts (molar ratio of $\mathrm{AlCl}_{3}$ : BPC about 1:1) the major $A l$-containing component anion in this composition is $\mathrm{AlCl}_{4}{ }^{-}$anion mainly, a small amount of the $\mathrm{Al}_{2} \mathrm{Cl}_{7}{ }^{-}$anion may be present at this composition. As for the $1.86: 1$ molar ratio of $\mathrm{AlCl}_{3}$ : BPC, there is no evidence from the Raman spectra [21] for the presence of $\mathrm{AlCl}_{4}^{-}$anions, but the $\mathrm{Al}_{2} \mathrm{Cl}_{7}^{-}$anion is the major species that present in the melt mostly. The structure of the melts can be demonstrated by considering the changes that occur as $\mathrm{AlCl}_{3}$ is added to BPC, initially, it reacts with the $\mathrm{Cl}^{-}$, forming a stable tetrachloroaluminate anion, i.e.,

\section{$2 \mathrm{AlCl}_{3}+2$ n-Bupy $\mathrm{Cl}=2 \mathrm{AlCl}_{4}^{-}+2$ n-Bupy ${ }^{+}$}

A the molar ratio of $\mathrm{AlCl}_{3}$ to $\mathrm{BPC}$ is greater than 1 or less than 2 , the second acid-base reaction occurs, i.e., 
$2 \mathrm{AlCl}_{3}+2 \mathrm{Bupy}+\mathrm{AlCl}_{4}{ }^{-}=2 \mathrm{Bupy}+\mathrm{Al}_{2} \mathrm{Cl}_{7}^{-}$

Normally thought, the convention adopted is to express the acid-base equilibrium as follows:

$$
2 \mathrm{AlCl}_{4}^{-}=\mathrm{Al}_{2} \mathrm{Cl}_{7}^{-}+\mathrm{Cl}^{-}
$$

Therefore, it is known that $\mathrm{AlCl}_{4}^{-}$and $\mathrm{Al}_{2} \mathrm{Cl}_{7}^{-}$are present in acid melts of binary $\mathrm{AlCl}_{3}{ }^{-} \mathrm{BPC}$ molten salt. As is evident from the structure of the melt, the aluminum is present as a negatively charged complex and thus it plays an important factors for discharge at cathode to deposit aluminum and only the $\mathrm{Al}_{2} \mathrm{Cl}_{7}^{-}$ canreduce to $A l$ at cathode in this binary system because of the much more negative reduction potenital of $\mathrm{AlCl}_{4}^{-}$than that of $\mathrm{n}-\mathrm{Bupy}^{+}$cation, and the electrochemical reaction of the discharge of $\mathrm{Al}_{2} \mathrm{Cl}_{7}^{-}$ ions in acid melts can be expressed as follows:

$$
4 \mathrm{Al}_{2} \mathrm{Cl}_{7}^{-}+3 \mathrm{e}^{-}=\mathrm{Al}+7 \mathrm{AlCl}_{4}^{-}
$$

The species present in the melts has been studied by Raman spectroscopy [21], as shown in Table 1, in which summarized the experimental Raman spectroscopy frequency shifts $\left(\mathrm{cm}^{-1}\right)$ for the vibrational peaks. It was observed in the low- $\mathrm{AlCl}_{3}$ content basic melt $(0.75 \sim 1)$, the frequencies assigned to $\mathrm{AlCl}_{4}{ }^{-}$anion. As the $\mathrm{AlCl}_{3}$ content increases, the bands assigned to $\mathrm{AlCl}_{4}{ }^{-}$do not contributed to the observed spectra but consistent with the frequencies of $\mathrm{Al}_{2} \mathrm{Cl}_{7}{ }^{-}$observed by Mamantor et al [22] and Øye et. al [23-24]. The large organic pyridinium cation R-Bupy+ does not influence the absorption frequencies of the anionic species $\mathrm{AlCl}_{4}{ }^{-}$or $\mathrm{Al}_{2} \mathrm{Cl}_{7}^{-}$, meanwhile, the interaction between pyridinium cation and anionic species is not appearance compared with that of the alkali metal cation on the $\mathrm{AlCl}_{4}{ }^{-}$anions, therefore, the aluminum electrode- posited process can be performed very well at cathode with the increasing the concentration of $\mathrm{AlCl}_{3}$ inspite of the large cation or anion species present.

As the molar ratio of $\mathrm{AlCl}_{3}$ to BPC increases from $1: 1$ to $1.86: 1$, the size of the crystal (particles) increases, Fig. 2 shows the SEM image distinctions between them. For the acidic melts, at low current densities, the discharge of $\mathrm{Al}_{2} \mathrm{Cl}_{7}^{-}$anion occurs on the cathode slowly, so the growth rate of nuclei should exceed the rate at which new ones form; the deposited particle obtained under these conditions should be large crystalline. As the current density increases, the formation of new nuclei is favoured and the deposited particle would be fine grained, at even higher current densities, the discharging rate is high enough to deplete the ions in the solution near the cathode. So that the deposites have to grow out to the higher concentration region and as a result the dendrites surface.

In Fig. 3 shows the results of SEM images at various electrodeposited conditions as current density increase from $20 \mathrm{~mA} / \mathrm{cm}^{2}$ to $80 \mathrm{~mA} / \mathrm{cm}^{2}$, the size of deposites particles decreases with increases the current density, because the formation rate of new neuclei is favoured. The size of deposites particles increase with increasing the electrodeposition duration at constant temperature $\left(30^{\circ} \mathrm{C}\right)$ and constant current density $\left(60 \mathrm{~mA} / \mathrm{cm}^{2}\right)$, the SEM images of electrodeposited layer is shown in Fig. 4. The thickness of the aluminum electrodeposited layer increases with increasing the duration of electrolysis as shown in Fig.5. The cross section of electrodeposition layer was determined by SEM as shown in Fig. 6, the composition of the Al-electrodeposited layer was examined by using the Auger Depth profile as shown in Fig. 7. In addition, the $X$-ray diffraction spectrums for the aluminum plate $(99.7 \%)$ and some aluminum

Table 1. Summary of experimental Raman frequency shifts $(1 / \mathrm{cm})$ for aluminum chloride: $n$-Butylpyridinium

\begin{tabular}{|c|c|c|c|c|}
\hline \multicolumn{5}{|c|}{ Molar ratio $\left[\mathrm{AlCl}_{3}\right]:[\mathrm{RC} 1]$} \\
\hline \multirow[t]{2}{*}{$0.75: 1.0$} & $1.0: 1.0$ & $1.5: 1.0$ & $1.74: 1.0$ & $2.0: 1.0$ \\
\hline & & $-95 \mathrm{sh}$ & $-102 \mathrm{sh}$ & \\
\hline \multirow[t]{2}{*}{$-126 \operatorname{sh}(0.9)$} & $-127 \operatorname{sh}(1.3)$ & $-126 \mathrm{sh}$ & & \\
\hline & & $-159(1.2)$ & $-163(1.5)$ & $-163(2.3)$ \\
\hline-1862.1$)$ & $-184(2.0)$ & $-183(2.8)$ & $-183(1.6)$ & $-182(0.9)$ \\
\hline \multirow{2}{*}{$-298(0.9)$} & $-295(0.7)$ & $-296 \operatorname{sh}(1.4)$ & $-295 \operatorname{sh}(1.6)$ & $-295 \operatorname{sh}(1.1)$ \\
\hline & & $-314(8.8)$ & $-316(10.0)$ & $-315(10.0)$ \\
\hline$-351(10.0)$ & $-352(10.0)$ & $-351(10.0)$ & $-352(5.0)$ & \\
\hline$-433(0.1)$ & $-433(0.1)$ & $-434(2.7)$ & $-433(3.3)$ & $-434(2.2)$ \\
\hline$-485(0.5)$ & $-483(0.4)$ & & & \\
\hline$-653(2.8)$ & $-650(2.4)$ & $-651(3.2)$ & $-647(4.7)$ & $-651(2.7)$ \\
\hline$-775(0.7)$ & $-770(0.5)$ & $-774(0.2)$ & $-772(0.2)$ & $-769(1.0)$ \\
\hline
\end{tabular}
chloride mixtures at room temperature [21].

$\mathrm{sh}=$ shoulder. 

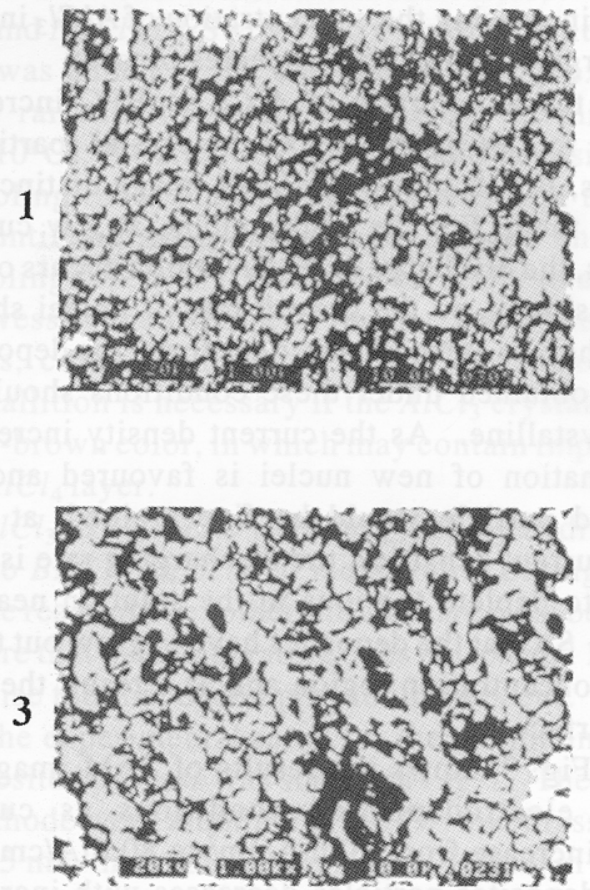
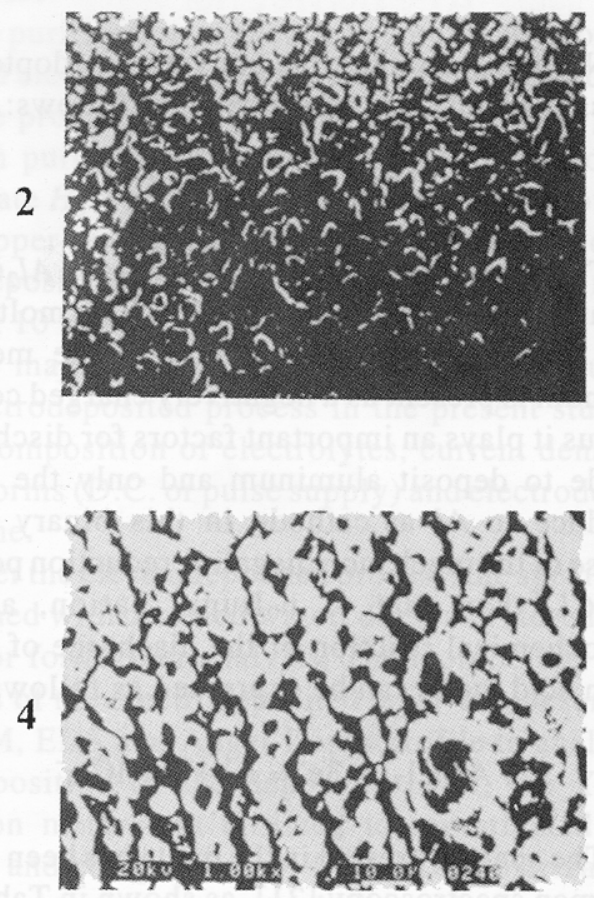

Fig. 2. Surface morphology of aluminum electrodeposited laye:: current density: $40 \mathrm{~mA} / \mathrm{cm}^{2}$ duration: $10 \mathrm{~min}$. substrate: brass plate $\begin{array}{llll}1.50: 50 & 2.55: 45 & 3.60: 40 & 4.65: 35\end{array}$
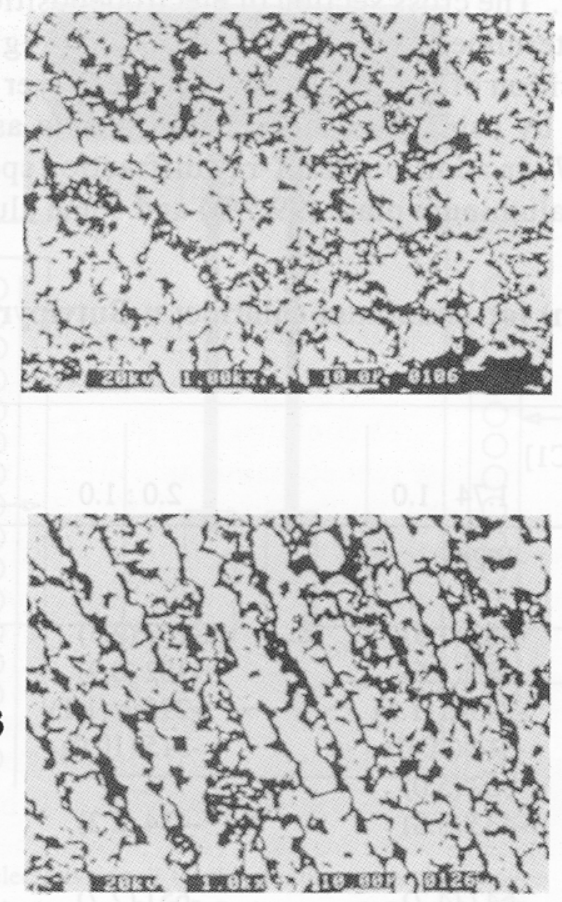
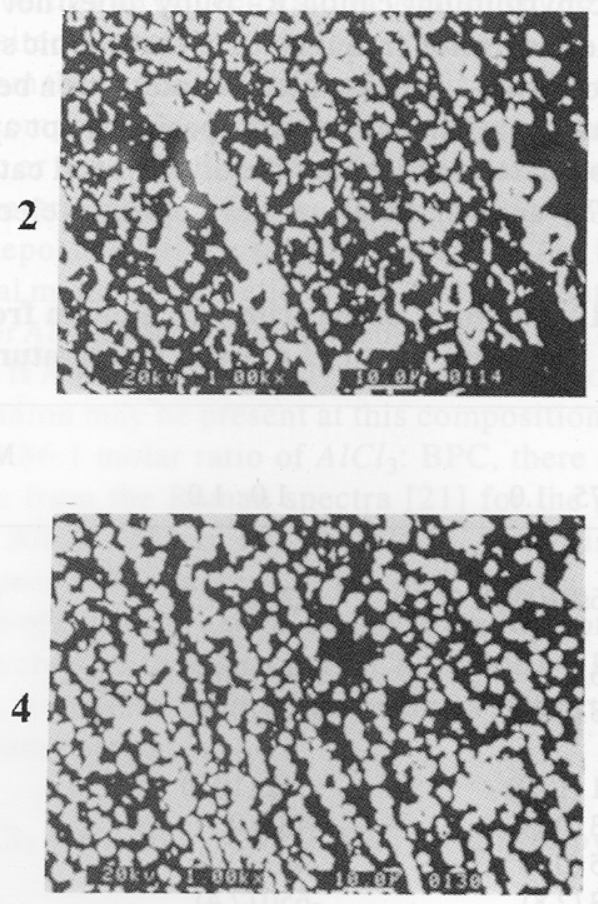

Fig. 3. Surface morphology of aluminum electrodeposited layer in an $\mathrm{AlCl}_{3}$ : BPC binary molten salt of molar ratio $1.5: 1$ at $30^{\circ} \mathrm{C}$ 1. $202.403 .604 .80 \mathrm{~mA} / \mathrm{cm}^{2}$ 

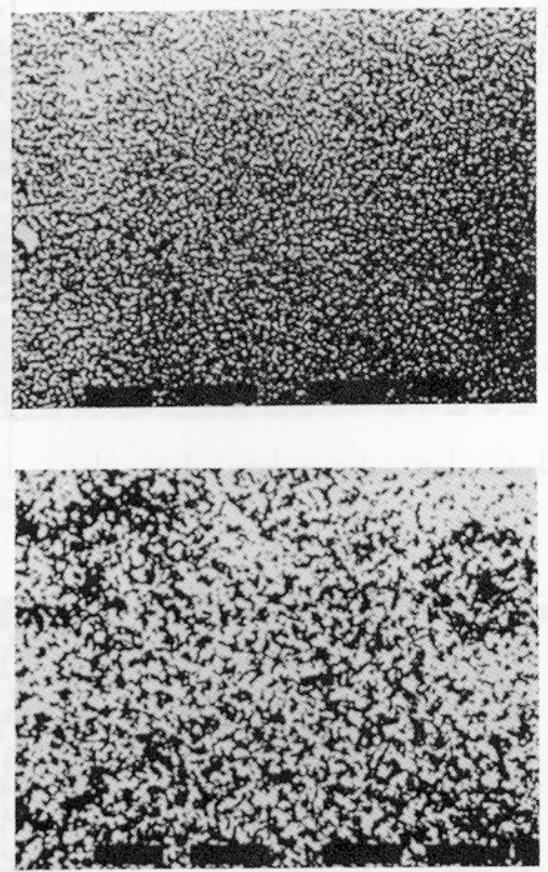

3

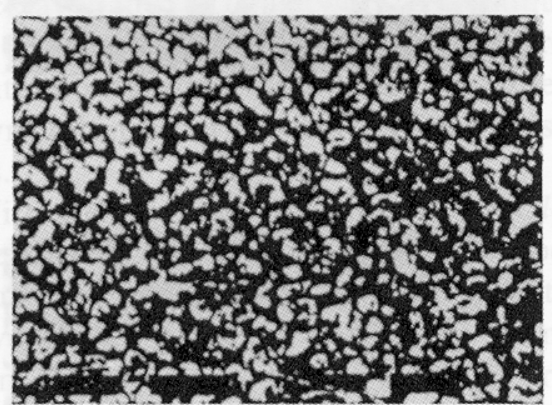

Fig. 4. Surface morphology of aluminum electrodeposited layer in an $\mathrm{AlCl}_{3}$ : $\mathrm{BPC}$ binary molten salt of molar ratio $1.5: 1$ at $30^{\circ} \mathrm{C}$ electrodeposited time : $1.5 \quad 2.10 \quad 3.15 \mathrm{~min}$.

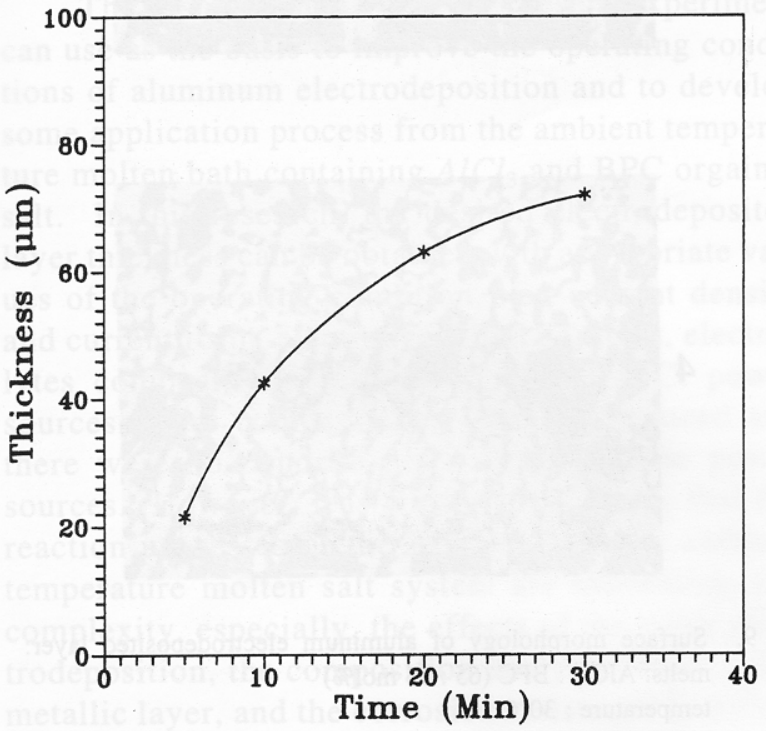

Fig. 5. The relationship between the electrodeposition time and the thickness of the aluminum electrodeposited layer.
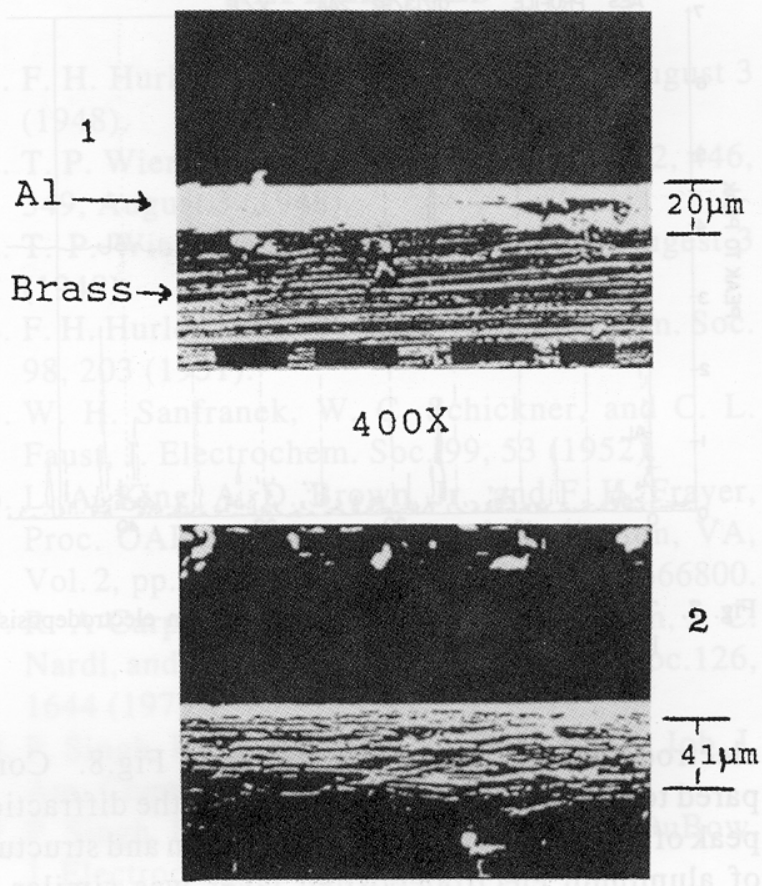

$400 X$

3

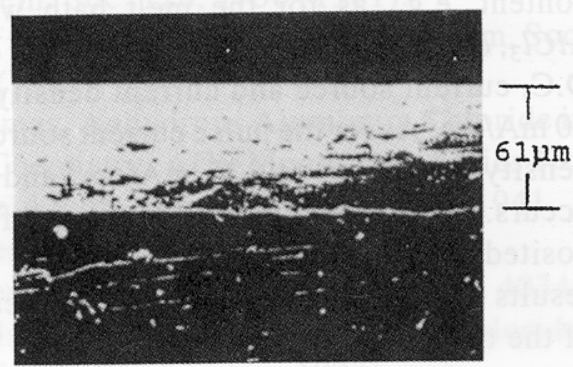

$400 X$

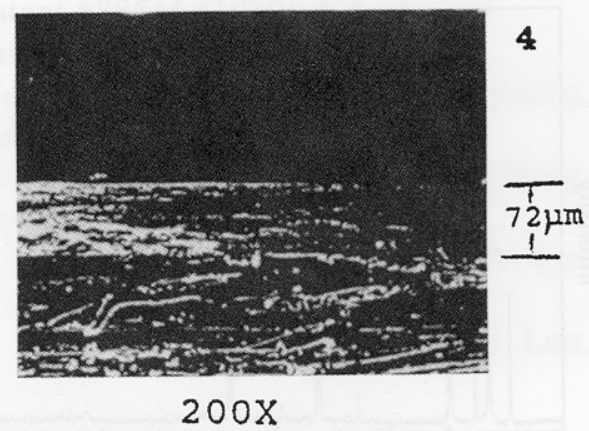

Fig. 6. The cross section of the aluminum electrodeposited layer. electrolyte: $\mathrm{AlCl}_{3}: \mathrm{NaCl}(63.67: 36.33 \mathrm{~mol} \%)$ temp : $30^{\circ} \mathrm{C}$

current density $: 40 \mathrm{~mA} / \mathrm{cm}^{2}$

D.C. power supply

substrate : brass plate

$1.5 \mathrm{~min} .2 .10 \mathrm{~min} .3 .20 \mathrm{~min} .4 .30 \mathrm{~min}$. 


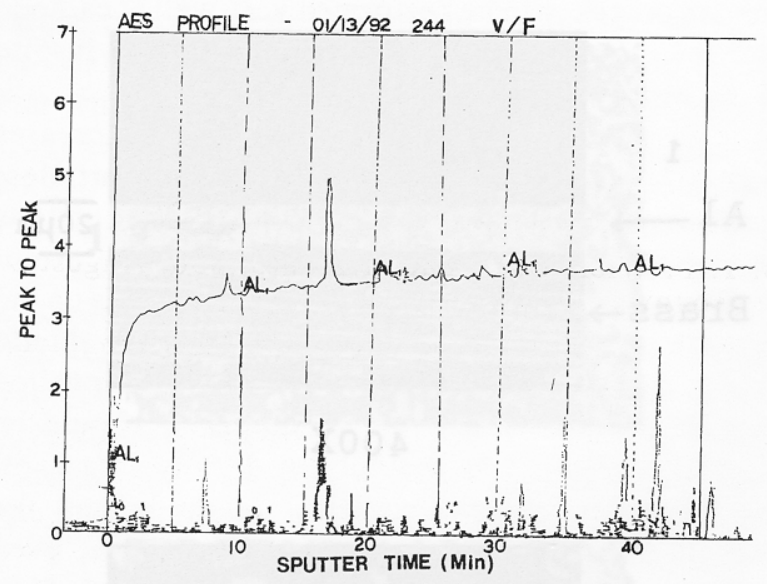

Fig. 7. The Auger Depth Profile of the aluminum electrodeposisted layer.

electrodeposited layer were shown in Fig.8. Compared to the experimental results, only the diffraction peak of $A l$ are observed, the composition and structure of aluminum electrodeposited layer was similar to that of pure plate $(99.7 \%)$. For the current density range in which an aluminum electrodeposited layer could be obtained become wider with increasing $\mathrm{AlCl}_{3}$ content, e.g., as for the melt bath with $65 \mathrm{~mol} \%$ $\mathrm{AlCl}_{3}$, densive and adhensive layer was obtained with D.C. current source and current density can be up to $80 \mathrm{~mA} / \mathrm{cm}^{2}$ As for the pulse current source, the current density can be up to $125 \mathrm{~mA} / \mathrm{cm}^{2}$ and no dendrites occurs. Fig. 9 shows the SEM images of $A l$ electrodeposited layer from both of them. Fig. 10 shows the results of polarization curves, it is indicated that both of the two curves had some tendency. Therefore we can concluded that the aluminum electrodeposited layer had the similar electrochemical properties to the pure $A l$ metal in aqueous solution.

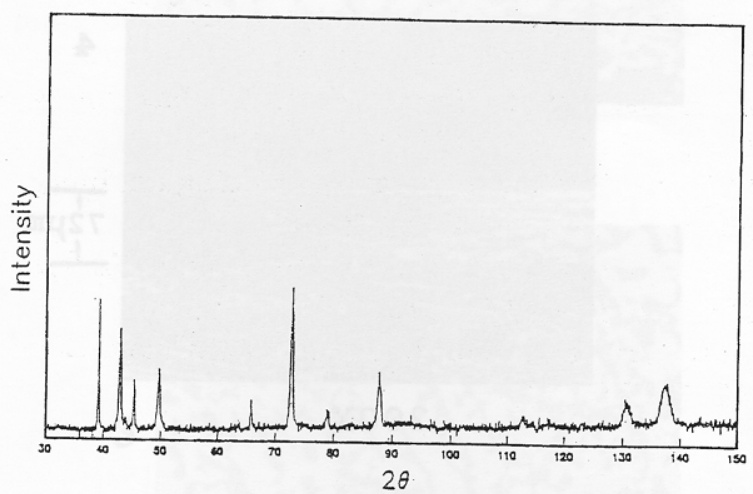

Fig. 8. The $X$-ray diffraction spectrum of the aluminum electrodepos ited layer:

electrolyte: $\mathrm{AlCl}_{3}$ : $\mathrm{BPC}(65: 35 \mathrm{~mol} \%)$

temp.: $30^{\circ} \mathrm{C}$

C.D. : $80 \mathrm{~mA} / \mathrm{cm}^{2}$

electrodeposited time : $10 \mathrm{~min}$.

substrate : brass plate
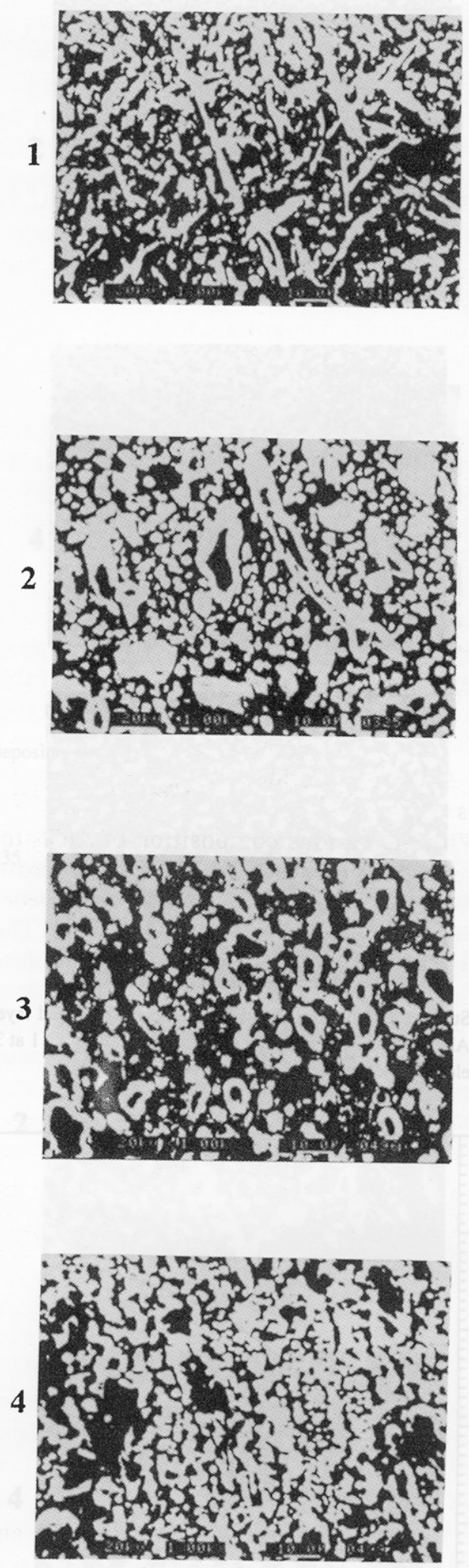

Fig. 9. Surface morphology of aluminum electrodeposited layer: melts: $\mathrm{AlCl}_{3}$ : BPC $(65: 35 \mathrm{~mol} \%)$ temperature : $30^{\circ} \mathrm{C}$

current density : $1.85 \mathrm{~mA} / \mathrm{cm} 2$

D.C. supply : (1) $5 \mathrm{~min}$. (2) $10 \mathrm{~min}$.

pulse power supply : (3) $5 \mathrm{~min}$. (4) $10 \mathrm{~min}$. 


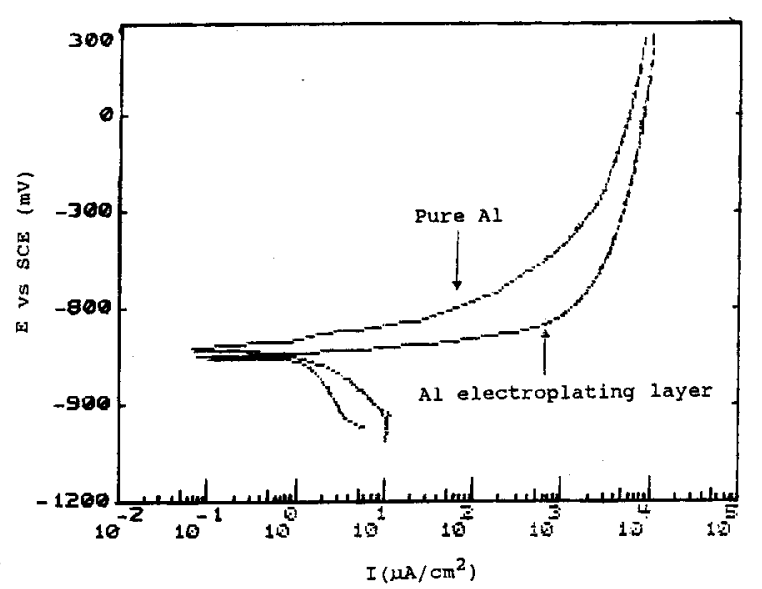

Fig. 10. The polarization curves of the aluminum electrodeposited layer and the pure aluminum plate.

\section{CONCLUSIONS}

The results collected here, indicated that the compact layer and the density of the aluminum layers can be obtained from the room temperature molten salt bath containing aluminum chloride and $n$ butylpyridinium chloride with D.C. and pulse current sources.

With the various composition of $\mathrm{AlCl}_{3}$ to BPC mixtures as electrolytes, aluminum was deposited on brass substrate and the quality of the $A l$ electrodeposited layer quite depended on the $\mathrm{AlCl}_{3}$ content, the optimum concentration range in an molar ratio of $\mathrm{AlCl}_{3}$ to BPC binary molten salt was from $1.5: 1$ to 1.86:1. Both D.C. and pulse current sources were used for the present study, and the well compact $A l$ electrodeposited layer was obtained.

The result gained from the present experiment can use as the basis to improve the operating conditions of aluminum electrodeposition and to develop some application process from the ambient temperature molten bath containing $\mathrm{AlCl}_{3}$ and BPC orgainic salt. In this research, the desired electrodeposited layer thickness can be obtained with appropriate values of the operating condition, i.e., current density and current form, electrodeposited duration, electrolytes composition. Compared to the D.C. power sources, more compact layer can be produced and there were no dendrite produce from pulse power sources. However, it is worth emphasizing that the reaction processes of the $A t$ species in the ambient temperature molten salt system are interesting and complexity, especially, the effects of the pulse electrodeposition, the composition analysis of the intermetallic layer, and the corrosion resistance in different environment for the various electrodeposited layer are required for further studies.

\section{REFERENCES}

1. F. H. Hurley, U. S. Patent 2, 446, 331, August 3 (1948).

2. T. P. Wier and F. H. Hurley, U. S. Patent 2, 446, 349, August 3 (1948).

3. T. P. Wier, U. S. Patent 2, 446, 350, Augest 3 (1948).

4. F. H. Hurley and T. P. Wier, J. Electrochem. Soc. 98,203 (1951).

5. W. H. Sanfranek, W. C. Schickner, and C. L. Faust, J. Electrochem. Soc. 99, 53 (1952).

6. L. A. King, A. D. Brown, Jr., and F. H. Frayer, Proc. OAR Applications Conf., Arlington, VA, Vol.2, pp.J1-J17, March 21, 1968, AD No.666800.

7. R. A Carpio, L. A. King, R. E. Lindstorm, J. C. Nardi, and C. L. Hussey, J. Electrochem. Soc.126, 1644 (1979).

8. P. Singh, K, Rajeshwar, J. DuBow, and R. Job, J. Am. Chem. Soc. 102, 4676 (1980).

9. P. Singh, R. Singh, K. Rajeshwar, and J. DuBow, J. Electrochem. Soc. 128, 1145 (1981).

10. P. Singh and K. Rajeshwar, J. Electrochem. Soc. 128, 1724 (1981).

11. K. Rajeshwar, P. Singh, and R. Thapar, J. Electrochem. Soc .128, 1750 (1981).

12. R. Thapar and K. Rajeshwar, J. Electrochem. Soc. 129,560 (1982).

13. C. A. Thomas, Anhydrous Aluminum Chloride in Organic Chemistry, ACS Monograph Series No. 87 Reinhold Publ. Corp., pp.864-8, 870, 1941.

14. U. S. Patent 409,668 (1889).

15. U. S. Patent 1, 645, 142-4 (1927); CA 21, 4034.

16. O. C. Ralston, Anhydrous Aluminum Chloride, Bureau of 321 (Washington. 1923).

17. N. N. Gratzians'kii, Ukrain. Khem. Zhur 9, 432 (1934).

18. U. S. Patent 422500 (1980).

19. French Patent 688566 (1930); CA 25, 780.

20. French Patent 1380362 (1964).

21. R. J. Gale, B. G. Ibert and R. A. Osteryoung, Inorg. Chem. 17, 2728 (1979).

22. G. Torsi, G. Mamantov, and G. M. Begum, Inorg. Nucl. Chem. Lett. 6, 553 (1970).

23. S. J. Cyvin, P. Klaoboe, E. Rytter, and H. A. Oye, J. Chem. Phys. 52, 2776 (1970).

24. E. Rytter, H. A. Oye, J. Inorg. Nucl. Chem. Lett. 35,1185 (1973). 